\title{
A figuração da violência na narrativa brasileira contemporânea: "Socorrinho", de Marcelino Freire
}

\section{A violence figuration in Brazilian contemporary narrative: "Socorrinho", by Marcelino Freire}

Fatima Aparecida Mantovani da Silva1, Vanderleia da Silva Oliveira²

Pós-graduanda no PROFLETRAS, UENP-CCP, Bolsista da CAPES, docente da SEED/PR.

E-mall. falima.amantovani@gmall.com Vunclada à UENP Centro de Lotras, COP CRELIT, e Artes e ao ProfLetras-Uenp, docente do Program de Pós-graduação em Letras da UEL. Organizou, com Ana Paula Franco Nobile Brandileone, a coletânea intitulada Desafios Contemporâneos: a escrita do agora, pela Annablume, em 2013.

E-mail: vances@uenp.edu.br
RESUMO: Análise do conto “Socorrinho", presente na obra Angu de sangue (2005), do escritor Marcelino Freire, com objetivo de demonstrar o modo pelo qual a temática da violência, discutida por Michaud (1989) - no caso específico do conto, trata-se do sequestro e estupro de uma menina - é abordada pelo autor, de acordo com as proposições de Schøllhammer (2000, 2009), Resende (2008), Pereira (2011), Brandileone (2013) e Oliveira (2013) em torno da narrativa brasileira contemporânea. Tal temática é observada pela análise do foco narrativo e do tempo, privilegiando, desse modo, a forma e o conteúdo, elementos indissociáveis da obra literária, conforme defendem Candido (1995) e Jouve (2012).

PalaVRAS-CHAVE: Violência; Narrativa contemporânea; Marcelino Freire.

ABSTRACT: An analysis of the tale "Socorrinho", present in the work Angu de sangue (2005), written by Marcelino Freire, aims to demonstrate the way in which the theme of violence, discussed by Michaud (1989) - in the specific case of the tale, that deal with a kidnapping and rape of a girl - is addressed by the author, according to the proposals made by Schollhammer $(2000,2009)$, Resende (2008), Pereira (2011), Brandileone (2013) and Oliveira (2013) around the Brazilian contemporary narrative. This issue is observed by the narrative focus and time analysis, privileging, thus, the form and content, inseparable elements of the literary work, as advocate Candido (1995) and Jouve (2012).

KEYwoRDS: Violence; Contemporary Narrative; Marcelino Freire. 


\section{A narrativa contemporânea}

egundo Candido (1989), de fato, a sociedade passou por processos de $\checkmark$ desumanização decorrentes do inchaço populacional dos grandes centros, do capitalismo massacrante, devido à industrialização, “[...] motivando a transformação das populações rurais em massas miseráveis e marginalizadas" (1989, p. 200). Tal cenário se concretiza nestes primeiros anos do século XXI nos grandes centros, onde sobrevive uma massa de excluídos.

A literatura não se desvincula desse processo histórico. As obras revelam de algum modo o seu tempo, seja na forma, seja no conteúdo, o que não quer dizer que devam ser lidas apenas no contexto de origem, pois a arte literária se atualiza a todo instante e pode ser "lida" em todas as épocas, produzindo diferentes significados, funcionando assim como sinal e como sintoma, de acordo com Jouve (2012).

Por isso, muitas delas recebem as influências da mídia, da televisão. Nesse sentido, Candido (1989) destaca a existência de uma linha experimental na década de 1960 e 1970, ocorrendo, na última, certa "legitimação da pluralidade" quando a literatura se renova na técnica, na linguagem e na concepção de narrativa, influenciada pelo jornalismo, pelas revistas, pelas propagandas, pela televisão e pelas vanguardas poéticas. Dessa produção, destacam-se, de acordo com o crítico, alguns contistas, pela “[...] penetração veemente no real graças a técnicas renovadoras, em que se mostram de maneira brutal a vida do crime e da prostituição", o que ele chama de "ultra-realismo" ou "realismo feroz" (1989, p. 210). Tal abordagem reaparece na narrativa do início do século XXI, renovada nos aspectos formais e ampliada quanto à temática da violência.

É o que demonstram os trabalhos de críticos como Resende (2008), Pereira (2011), Schøllhammer (2009), Oliveira (2013) e Brandileone (2013), os quais se arriscam, segundo alguns deles, pela falta de distanciamento temporal entre crítico e obra, em apontar algumas características da narrativa do "agora", usando aqui a expressão de Brandileone e Oliveira, referindo-se à produção do século XXI. Para Brandileone, o que é inegável na literatura a partir de 80 e 90 é a ênfase na diversidade, pois não há "[...] um projeto estético ou político único, cujos traços possibilitem defini-la sob um rótulo". E essa diversidade é integrada ao texto literário no que se refere aos gêneros, aos suportes, aos temas e às imagens (2013, p. 17).

Entretanto, dentro dessa multiplicidade e diversidade, há três aspectos em comum, são eles: o da presentificação, que é a preocupação em falar do tempo presente - o que se percebe na forma, visto que os textos são curtos, e nos temas, que são atuais; o da presença do trágico, que prevalece na vida e no destino dos personagens; e o da violência que se mostra:

[...] na urgência da presentificação e [na] dominância do trágico, em angústia recorrente, com a inserção do autor contemporâneo na grande cidade, na metrópole imersa numa realidade temporal de trocas tão globais quanto barbaramente desiguais. (RESENDE, 2008, p. 33)

Como bem salientou Oliveira (2013), a violência sempre esteve presente nas narrativas, inclusive na Bíblia, mas, segundo a autora, o que importa é como essa temática se produz no "domínio estético-discursivo", isto é, de que forma a realidade é transfigurada em arte literária. Novamente, ouvem-se ecos de Candido sobre a relevância de se considerar a forma e o conteúdo, pois "[...] o conteúdo só atua por causa da forma, e a forma traz em si, virtualmente, uma capacidade de humanizar devido à coerência mental que pressupõe e que sugere" (CANDIDO, 1995, p. 246).

Oliveira (2013), a partir das ponderações de Schøllhammer (2000), alerta para o fato de que a violência sempre esteve no campo e no urbano e, além disso, sob diferentes aspectos. No mundo contemporâneo há violência em escalas inimagináveis em outros tempos e em outros espaços. Por isso, o escritor do "agora", afeito à temática da violência, elege como espaço os 
grandes centros urbanos e o tempo presente como elementos de observação e/ou experiência.

Observam-se, portanto, variadas formas de violência, algumas ligadas às minorias (étnicas, sexuais, sociais), como, por exemplo, alienação, preconceito, segregação, autoritarismo, que se concretizam em criminalidade, assassinato, estupro, roubo, violência linguística, pedofilia e outros (BRANDILEONE; OLIVEIRA, 2014). Em tempos não muito distantes, a ofensa ao negro não era considerada crime. Basta lembrar o preconceito e a exclusão pelos quais passou o personagem Isaías, da obra Recordações do escrivão Isaías Caminha, e também da vida de seu autor, Lima Barreto, que teve dificuldades para publicar o referido romance por ser negro. Isso para ficar apenas no âmbito literário e em apenas um exemplo. Todavia, se a temática da violência é comum aos escritores na narrativa contemporânea, os recursos estilísticos e técnicos de cada um deles são diversificados, por isso é interessante analisar, retomando Oliveira (2013), o "domínio estético-discursivo".

Com recursos variados, os escritores contemporâneos desejam “[...] provocar efeitos de realidade por outros meios", diferente do Realismo do século XIX (SCHØLLHAMMER, 2009, p. 54). Para o autor, tais meios revelam um novo realismo, que se constitui na apreensão da realidade - sem ser mimético ou representativo - por meio do olhar estético do autor, a qual se concretiza no e pelo discurso literário, configurando-se em arte - o texto literário, que, por sua vez, chega ao leitor, dotado de uma força transformadora, mas sem nenhum vínculo a movimento literário ou político.

[...] o novo realismo se expressa pela vontade de relacionar a literatura e a arte com a realidade social e cultural da qual emerge, incorporando essa realidade esteticamente dentro da obra e situando a própria produção artística como força transformadora. Estamos falando de um tipo de realismo que conjuga as ambições de ser "referencial", sem necessariamente ser representativo, e ser, simultaneamente, "engajado", sem necessariamente subscrever nenhum programa político ou pretender transmitir de forma coercitiva conteúdos ideológicos prévios. (SCHØLLHAMMER, 2009, p. 54)
Muda-se, assim, a forma de representação, que, tradicionalmente, era linear e unívoca, representando as certezas do homem da época, certezas agora abaladas. Marcelino Freire é um dos representantes desse novo realismo, uma vez que "[...] percebemos a continuidade de uma prosa direta e pungente, sem rodeios nem floreios, abordando temas convulsivos e procurando extrair deles sua máxima força" (SCHøLLHAMMER, 2009, p. 59).

Brandileone e Oliveira (2014), recorrendo às considerações de Schøllhammer (2009) e Helena Bonito Pereira (2011), apontam algumas características da nova narrativa atual, que apresenta formas breves, linguagem fragmentada, esta advinda da tecnologia e de outras mídias que

[...] se manifesta na linguagem narrativa pelos vazios na página escrita, por cortes abruptos no tempo e espaço diegéticos, bem como por múltiplos planos temporais e espaciais que se interpenetram, comprometendo a coerência e contribuindo para a instauração do caos que, não raro, se associa às personagens, cada vez mais problemáticas; anti-heróis em permanente dissonância com o mundo. (BRANDILEONE; OLIVEIRA, 2014 p. 25-6)

Assim, pode-se sintetizar que na "escrita do agora", fazendo referência ao título do livro das autoras acima referenciadas, as principais marcas são: a preferência pela temática da violência, a qual opera um descentramento, trazendo para o centro da discussão as minorias e as massas excluídas; brevidade dos contos para atender ao critério da presentificação e da urgência, o que leva o leitor à leitura ávida e dinâmica. Há ainda ausência da ordem linear temporal e do espaço definido; a presença do personagem marginal desajustado no mundo e em conflito com ele; fragmentação discursiva, voz do marginalizado (prostitutas, ex-detentos, negros) por ele mesmo ou por meio de diferentes narradores.

Ainda, segundo Brandileone, em algumas obras da ficção contemporânea, há outro recurso também advindo da mídia: a presença do "[...] narrador de 
grau zero, isto é, narrativas que subtraem totalmente a figura do narrador" (2013, p. 23). Em vez de contar, vale o "mostrar" e "Os personagens tornamse atores do drama a ser levado em cena". Nessa linha, diz Brandileone, a literatura deixa de ser mediação, para ser imediação, uma vez que se deseja apresentar ao leitor de forma direta "como reprodução imediata do real" (2013, p. 24). Oliveira (2013, p. 39) destaca ainda que, ao lado da temática da violência, há o "[...] exercício da metalinguagem, tematizando a própria escritura". Vale dizer também que a violência não se dá somente pelo conteúdo, mas pela forma, pela linguagem chocante, ágil, veloz e direta.

\section{A contística do século XXI e a produção de Marcelino Freire}

O conto, considerado por muitos estudiosos como gênero de difícil definição, conhecido como narrativa curta, poucos personagens, um só conflito, encontra em Cortázar uma definição, que vai além da estrutura. De acordo com ele, o conto é uma “[...] síntese implacável de uma certa condição humana" ou mesmo um "[...] símbolo candente de uma ordem social ou histórica”, o qual “[...] quebra seus próprios limites com essa explosão de energia espiritual que ilumina bruscamente algo que vai muito além da pequena e às vezes miserável história que conta" (2011, p. 153).

Esse gênero, que já brilhou nas mãos de Machado de Assis, chega renovado aos dias atuais, no que se refere às técnicas e também a alguns temas, e isso ocorre porque, de acordo com Gotlib (2006, p. 30), para os modernos, a estrutura clássica com começo, meio e fim pode ser quebrada e invertida, porque uma realidade pode ser desdobrada “[...] em tantas configurações quantas são as experiências de cada um". É o que conclui Rinaldo Fernandes (2010), para quem o conto é o gênero de destaque na literatura do início do século porque produz desestabilização formal, o que não é tão evidente no romance, por exemplo.
Os contistas, por sua vez, estão num momento muito instigante. Nota-se uma variedade de formas no conto, que vai do minimalismo ao realismo brutal, passando pela vertente intimista (ainda nas pegadas de Clarice Lispector), pela narrativa fragmentária ou mesmo experimental. 0 conto tem narrado situações típicas do homem contemporâneo - como, por exemplo, a violência ou mesmo a penúria, a miséria brasileira - de forma aguda, veemente [...] (FERNANDES, 2010, p. 11).

Fernandes cita como exemplos desse novo conto aqueles produzidos no Nordeste, região celeiro de bons escritores, situando Marcelino Freire entre eles. Essa literatura nova, urbana, nordestina, segundo ele, já se consolidou e, por tratar de problemas semelhantes aos dos grandes centros, apresenta muitas similaridades com as narrativas do Sul e Sudeste, de modo geral. Analisando essa produção, ele detectou cinco vertentes principais do conto:

[...] 1) a da violência ou brutalidade no espaço público e urbano; 2) a das relações privadas, na família ou no trabalho, em que aparecem indivíduos com valores degradados, com perversões e não raro em situações também de extrema violência, física ou psicológica; 3) a das narrativas fantásticas, na melhor tradição do realismo fantástico hispano-americano, às quais se podem juntar as de ficção científica e as de teor místico/macabro; 4) a dos relatos rurais, ainda em diálogo com a tradição regionalista; 5) a das obras metaficcionais ou de inspiração pós-moderna (FERNANDES, 2010, p. 11).

Destaca, ainda, que, apesar das diferenças, há algo que une essas vertentes - o "olhar cruel e irônico" da existência, herdado de Machado de Assis. Marcelino Freire, autor de "Socorrinho", da obra Angu de Sangue (2005), é representante da primeira vertente, denominada por Fernandes como "a da violência ou brutalidade no espaço público e urbano".

Marcelino Freire, pernambucano, editor e escritor, vive em São Paulo desde 1991. É autor de EraOdito (Aforismos, 2ª edição, 2002), Angu de Sangue (Contos, 2000) e BaléRalé (Contos, 2003). É um dos contistas em destaque nas antologias Geração 90 (2001) e Os transgressores (2003), publicadas 
pela Boitempo Editorial. Autor de Contos negreiros, Prêmio Jabuti 2006. Em 2004, idealizou e organizou a antologia de microcontos Os cem menores contos brasileiros do século. Publicou a coletânea de contos Amar é crime (2011). Em 2013, publicou seu primeiro romance, intitulado Nossos ossos, com o qual ganhou o prêmio Machado de Assis em 2014. Adenize Franco, ao analisar a obra Amar é crime, sintetiza suas observações sobre o escritor:

Utilizando temas atuais e situações violentas que foram midiatizadas e, por isso, facilmente reconhecíveis pelo leitor, assim como o reconhecimento dessas identidades perdidas em meio ao caos que impera na urbe contemporânea, Marcelino Freire consegue explorar a tragédia social brasileira a partir de uma linguagem que é incômoda e provocativa, permeada por cacoetes sonoros e ritmos fervorosos. Estas características, por um lado, singularizam a obra desse escritor contemporâneo que cada vez mais ganha visibilidade no cenário da literatura brasileira e, por outro, pluralizam as questões de cunho social (FRANCO, 2011, p. 86).

Pode-se dizer que no conto "Socorrinho", Freire (2005), além de lidar com outras funções peculiares do texto literário, longe de ser panfletário ou sentimentalista, cumpre com uma função sinalizada por Érico Veríssimo:

0 menos que um escritor pode fazer, numa época de atrocidades como a nossa, é acender a sua lâmpada, fazer luz sobre a realidade de seu mundo, evitando que sobre ele caia a escuridão, propícia aos ladrões, aos assassinos e aos tiranos. Sim, segurar a lâmpada, a despeito da náusea e do horror. Se não tivermos uma lâmpada elétrica, acendamos o nosso toco de vela ou, em último caso, risquemos fósforos repetidamente, como sinal de que não desertamos nosso posto. (VERÍSSIMO, 1978, p. 7)

\subsection{Desdobramentos da violência em Socorrinho}

O conto "Socorrinho" narra o desaparecimento e estupro de Maria do Socorro Alves da Costa, uma menina de seis ou sete anos, fato que provoca o sofrimento e desespero da família, moradora da cidade grande, palco de violências em suas múltiplas formas. Para Yves Michaud:
Há violência quando, numa situação de interação, um ou vários atores agem de maneira direta ou indireta, maciça ou esparsa, causando danos a uma ou várias pessoas em graus variáveis, seja em sua integridade física, seja em sua integridade moral, em suas posses, ou em suas participações simbólicas e culturais (MICHAUD, 1989, p. 11).

A violência a que Socorrinho foi exposta é de ordem física e moral, não apenas atingindo-a, mas também a seus familiares, que também sofrem violência quando tentam encontrar a menina com os seus poucos recursos financeiros. Por isso, o objetivo dessa análise é demonstrar como o desaparecimento e a violência sexual sofrida por Socorrinho ocorrem e se desdobram em outras formas de violência, nos espaços urbanos, e como essa temática emerge no texto pela estrutura da narrativa contemporânea, especialmente pelo foco narrativo, o qual interfere no elemento temporal. Ainda, na medida do possível, serão exemplificados alguns recursos do chamado novo realismo empreendido por Freire no referido conto.

É relevante destacar a importância de se analisar o texto literário no que se refere à forma e ao conteúdo, pois ambos são indissociáveis, visto que o estético passa pela forma (CANDIDO, 1995). Por isso, a presente análise adota uma linha próxima a de Antônio Candido, em que se consideram os aspectos estéticos e linguísticos do texto e também aqueles ligados à sociedade, visto que a arte percorre um caminho de mão dupla: capta a realidade pelo olhar artístico do escritor e devolve a essa realidade o texto literário, podendo transformá-la (CANDIDO, 2000).

A realidade violenta - desaparecimento e estupro de Socorrinho - é apresentada ao leitor por diversas vozes - narrador, personagens, instituições - por isso há também o cruzamento de diferentes discursos: do narrador, da imprensa, da mãe, de vizinhos, do estuprador e da polícia. Essas vozes revelam não apenas uma linguagem de diferentes níveis - objetiva, poética, oral, sensacionalista - como também ideologias e práticas sociais diversas. 
Tudo isso escrito em um único parágrafo, em uma só frase e em apenas duas páginas, em um estilo sintético e dinâmico. Integram-se a essa concisão e dinamismo, palavras de sentidos dúbios, trechos poéticos e sonoros, simultaneidades de acontecimentos.

A temática da violência se constrói amalgamada a esses recursos, os quais, portanto, não são meros veículos do conteúdo, mas também produtores de sentido e reiteradores da temática tratada, tendo o autor o objetivo de criticá-la, mas sem fazer da obra um panfleto. Ao contrário, o conto analisado é construído com muito cuidado estético, sem perder a visão histórica e a realidade social.

Verifica-se, assim, que, ocorre a situação registrada por Pedro Lyra, para quem a literatura brasileira se tornou "[...] uma literatura violenta, de condenação da violência - tanto na desintegração da forma quanto no desnudamento da linguagem, tanto no rompimento do discurso quanto na exacerbação do tema" (1980. p. 6). De fato, em "Socorrinho", não há descrições, detalhes e explicações, a narrativa corre a galope assim como corre a vida nas grandes cidades: [...] "Socorrinho, algumas buzinas, céu de gasolina, ozônio, cheiro de álcool, moço, não [...]” (FREIRE, 2005, p. 47).

A construção textual, embora pareça ser simples, exige um leitor capaz de completar os espaços em branco do texto, associar ideias e refletir. Isso significa que o conhecimento prévio do leitor e suas experiências são importantes para a significação e atualização da obra, conforme expôs Jouve:

É precisamente o caráter diferido da comunicação literária que, de certa forma, faz a riqueza dos textos. Recebido fora de seu contexto de origem, o livro se abre para uma pluralidade de interpretações: cada leitor novo traz consigo sua experiência, sua cultura e os valores de sua época (JOUVE, 2002, p. 24).

O leitor não vai encontrar em "Socorrinho" uma narrativa óbvia e linear, visto que a escolha do foco narrativo e o trabalho com o elemento tempo não permitem que isso se dê. O foco narrativo, de acordo com Arnaldo Franco Junior, é um recurso adotado pelo narrador para enquadrar a história de um determinado ângulo ou ponto de vista, mas não basta verificar apenas isso, uma vez que o tipo de focalização “[...] evidencia o propósito do narrador (e, por extensão, do autor) de mobilizar intelectual e emocionalmente o leitor, manipulando-o para aderir às ideias e valores que veicula ao contar a história" (FRANCO JUNIOR, 2009, p. 42). Em outras palavras, a análise da estrutura da obra é válida se ela colaborar para a produção de significados, contribuindo na interpretação.

A narrativa de Freire não se limita a um único ponto de vista, já que é construída a partir de vários ângulos que se sobrepõem uns aos outros: o do narrador em terceira pessoa no discurso indireto, o de alguns personagens pelo discurso direto de forma não convencional, isto é, sem aspas ou travessão, e outras vozes sociais que, amalgamadas à do narrador, constituem o discurso indireto livre.

Alguns personagens surgem na história, em alguns momentos, pela própria voz, como se o narrador estivesse em vários espaços e tempos da diegese, simultaneamente, com uma câmera na mão e um microfone, cedendo voz a todas as partes envolvidas, semelhante a uma reportagem investigativa, em que todos os lados são ouvidos. Entretanto, o narrador não aparece para mediar todas as falas, em muitas ocasiões ele praticamente desaparece (narrador de grau zero), privilegiando a cena que se mostra diretamente ao leitor, em que se identifica facilmente quem é que fala, em primeira pessoa. Em outros momentos, as vozes se confundem podendo ser a do narrador e de mais de um personagem, como no trecho "Moço, não, descaso, não escuto, moço não" (FREIRE, 2005, p. 48). Há, neste fragmento, a fala da garota em "Moço, não", a do criminoso ou uma voz geral da sociedade em "não escuto" e a do narrador ou de qualquer pessoa da vizinhança em "descaso". Isso é possível graças à técnica do discurso indireto livre, que 
[...] é a representação da fala e/ou pensamento das personagens. De caráter híbrido, esse tipo de discurso permite que a voz da personagem penetre a estrutura formal do discurso do narrador "como se ambos falassem em uníssono, fazendo emergir uma voz dual" (DUARTE, 2006, p. 47).

Assim, o fato de Marcelino Freire não pertencer ao espaço marginalizado, não tendo, portanto, o "olhar de dentro" do qual falou Resende (2008), em nada fere o seu intento de focalizar um universo à margem da sociedade. Ele se coloca ao lado das minorias, dentro do espaço focalizado, na medida em que cede voz a essas minorias pelo discurso direto e principalmente quando aproxima seu próprio discurso dos discursos dos marginalizados por meio do discurso indireto livre. Revela, dessa forma, sua solidariedade e sua empatia com alguns personagens e com algumas situações, sem ser piegas, sem objetificar os personagens, conservando-lhes a condição de sujeitos. Isso pode ser observado no seguinte trecho: "[...] Socorrinho desaparecida, amor quando vai embora, quando vira fé, chamado, súplica, saudade, a filha fosse devolvida, a felicidade, moço, não [...]" (FREIRE, 2005, 48).

Sobre essa função do discurso indireto livre, Reis \& Lopes (1988), trazendo a voz de Bakhtin (2006), defendem:

[...] ao proporcionar uma confluência de vozes, marca sempre, de forma mais ou menos difusa, a atitude do narrador em face das personagens, atitude essa que pode ser de distanciamento irônico ou satírico, ou de acentuada empatia (REIS; LOPES, 1988, p. 277, apud DUARTE, 2006, p. 47, grifo nosso).

A voz do narrador - "os acentos e as entoações" - nesse discurso duplo é interrompida pelos "julgamentos de valor de outra pessoa" (BAKHTIN, 2006, p. 196), isto é, de um personagem. Conclui-se que entre narrador e personagem não existe uma voz mais forte, mais autoritária, capaz de concluir o diálogo e ditar uma verdade absoluta, vez que é "precisamente a multiplicidade de consciências equipolentes e seus mundos que aqui se combinam numa unidade de acontecimento, mantendo a sua imiscibilidade", configurando a polifonia e tornando o diálogo inacabado. (BAKHTIN, 2008, p. 4).

A predominância do discurso indireto livre, a falta aparente de sequência sintática, a ausência de paragrafação e a ausência da demarcação das vozes criam um texto fragmentado. Essa fragmentação, portanto, não compromete a percepção do leitor sobre a realidade ali narrada, graças à cena, em que o mostrar é mais importante do que o contar, visto que "Os personagens tornam-se atores do drama a ser levado em cena" (BRANDILEONE, 2013, p. 23). Trata-se de uma maneira peculiar na forma de narrar, tanto que é muito difícil usar nomenclaturas tradicionais para explicar a focalização e outros elementos do conto analisado porque:

Há uma mescla de vozes ("eu", "nós", "ele", "ela"). Muitas vezes, temos de reler os diálogos para conseguirmos entender a quem pertence determinada fala. [...]. Muitas vezes, fica para o leitor a impressão de estar percorrendo um site de maneira veloz [...] (FERNANDES, 2009, p. 302).

Algumas narrativas, embora apresentem várias vozes, subordinam-nas à visão do narrador/autor e assim todas contribuem para confirmar a ideologia que ele deseja disseminar. Tal procedimento é chamado por Bakhtin (2008) de "monológico", uma vez que todas as vozes convergem para um único ponto de vista, o do autor. Não é o que se observa no conto "Socorrinho", em que as diferentes vozes se debatem e se polemizam, expondo variados modos de ver o mundo, como se percebe no trecho "[...] viver agora o que seria se já não era, se por um descuido já se foi um dia sem ela, dois, Socorrinho, céus e preces moço, não, Maria do Socorro Alves da Costa, mulatinha, [...]" (FREIRE, 2005, p. 48, grifo nosso).

Nesse excerto, não apenas há vários posicionamentos, como há uma voz que é, possivelmente, do narrador, entrecortada por outra voz que 
chama a menina, como se pode observar em: “[...] se por um descuido já se foi um dia sem ela, dois, socorrinho, [...]"(FREIRE, 2005, p. 48). A palavra "descuido" pode ser vista como uma forma de não isentar a família de alguma responsabilidade pelo desaparecimento da menina. Desse modo, Freire minimiza a vitimização da família, reduzindo o perigo de despertar no leitor o sentimento de pena, o que não se pretende, uma vez que se deseja chocar o leitor, como no exemplo a seguir: "[...] que miséria, agonia de cidade, moço, não, gente ruim, sem sentimento, pra que deixar sofrendo a mãe humilde, o bairro, a câmera de TV que treme aquela realidade de cão, mundo, cachorro [...]" (FREIRE, 2005, p. 48).

Constituindo-se em uma narrativa aparentemente caótica, pelas técnicas empregadas, muitas delas inspiradas na mídia, representam-se, também, a confusão vivida pela menina nas mãos de seu algoz, bem como a da família. Isso é percebido tanto no nível do conteúdo quanto no nível da forma. No nível do conteúdo, tal confusão é explicitada nos seguintes fragmentos: “[...] Socorrinho mais não entendia aquele mundo estranho[...]" (FREIRE, 2005, p. 49), “[...] o marido já enlouquecido e internado [...]” (FREIRE, 2005, p. 48). No nível da forma, a confusão da menina, que se mescla à confusão e ao barulho da cidade, concretiza-se pela justaposição dos discursos de diferentes vozes, ora trazidas à cena pelo discurso indireto, direto e indireto livre, como se observa no seguinte excerto:

O marido já enlouquecido e internado, que miséria, agonia de cidade, moço, não, gente ruim, sem sentimento, pra que deixar sofrendo a mãe humilde, 0 bairro, a câmera de tv que treme aquela realidade de cão, mundo, cachorro, já noitinha de outra noite, mais outra, notícia mais nenhuma, nunca, Socorrinho desaparecida [...] (FREIRE, 2005, p. 48).

No fragmento seguinte percebe-se a confusão da garota e sua incapacidade de compreender o que está vivendo, mas que não a impede de intuir que algo de ruim vai lhe acontecer. Incompreensão que se manifesta no conteúdo e, especialmente, na forma, na mistura de sua fala com a do narrador em terceira pessoa: [...] moço não, não, parecido sonho ruim, dor de dente, comprimido, pernilongo, extração de ouvido, o ônibus elétrico, esquinas em choques, paralelepípedos, viagens que não conhece [...] (FREIRE, 2005, p. 47). A expressão fora do lugar comum "extração de ouvido" reafirma a confusão vivida pela garota e salienta o sofrimento, pois se extração de dente dói, de ouvido é incalculável.

Também a imagem "esquinas em choques" demonstra a simbiose do espaço agitado e nervoso da cidade com o choque pelo qual passa a menina. Além disso, as expressões "sonho ruim", "dor de dente", "comprimido" logo após a fala da menina, que parecem fazer parte dos medos infantis experimentados por ela em seus seis ou sete anos de vida, aproximam esse narrador de fora ao universo daquele que sofre, diminuindo o distanciamento entre narrador e narrado, configurando um recurso importante para provocar o "efeito de realidade por outros meios", do qual tratou Schøllhammer (2009, p. 54).

O trecho já transcrito "Socorrinho, algumas buzinas, céu de gasolina, ozônio, cheiro de álcool, moço, não" (FREIRE, 2005, p. 47), por exemplo, é construído pela voz da mãe, que chama a menina sumida em "Socorrinho", a do narrador em "algumas buzinas, céu de gasolina, ozônio, cheiro de álcool", e a da garota em "Moço, não", demonstra de modo simultâneo que tudo acontece ao mesmo tempo, na urbe, onde se aglomeram pessoas, acumulam-se barulhos, cheiros e violência. $\mathrm{O}$ autor não monopoliza a narração, delegando esse trabalho a outros envolvidos na história pelo entrecruzar desconexos de vozes, característicos da vida real, da rua, da cidade, o que aproxima o leitor à obra. Esse é mais um dos recursos referidos por Schøllhammer (2009) para provocar efeito de realidade.

Observa-se, também, no fragmento anterior a ausência de adjetivos na caracterização do espaço, que é apresentado ao leitor de modo 
cinematográfico, sem conectivos, lembrando algumas produções da primeira fase modernista, como as de Oswald de Andrade e Mário de Andrade. Essa economia linguística, essa rapidez do narrar colabora para a significação do texto. Pode-se dizer que, esse modo ligeiro, dinâmico e sintético, aliado ao conteúdo - o estupro e desaparecimento da menina no espaço urbano signifiquem a rapidez do mundo atual, a pressa das pessoas, a correria da vida moderna e, por isso, ninguém pôde ouvir a menina gritando, ninguém a viu sofrer, ninguém tinha notícia da menina. A pressa sufocou o grito de Socorrinho, o chamado da mãe e cegou as pessoas. "Moço, não, [...]”; “[...] dia de calor, calor enorme, ninguém que avista [...]” (FREIRE, 2005, p. 47).

O próprio título do conto "Socorrinho", diminutivo do segundo nome da menina (Socorro), sugere uma forma carinhosa de tratar a menina, vítima da violência da cidade, mas, principalmente, simboliza o seu grito pequeno, curto e repetido, no sentido literal e metafórico, sem importância para a sociedade, a não ser para a família - "Moço, não" (FREIRE, 2005). A própria escritura atesta isso pela voz do narrador em terceira pessoa: “[...], aquele grito franzino, miúdo [...] (FREIRE, 2005, p. 47) e pela voz de Socorrinho "Moço, não", que dá início ao conto e o permeia até o final, repetida por doze vezes, sendo que na última ocorrência, nas linhas finais, é acrescentado um "não" a mais. "[...] Moço, não, não" (FREIRE, 2005, p. 49).

Essa inserção de mais um advérbio de negação não é por acaso, pois significa que a menina não escapou da violência sexual, ela implorou o tempo todo e sua voz ecoa paralelamente à narração do conto até o final, para que esse fato se presentificasse. Recurso diferente da narrativa tradicional, que utiliza algumas estratégias narrativas, como a descrição, por exemplo, para suspender os acontecimentos com o objetivo de baixar a tensão do leitor. $\mathrm{O}$ pedido recorrente da menina constitui-se em mais um recurso para criar o efeito de real em uma obra que, como afirmou Schøllhammer (2009), não quer ser realista ao modo do Realismo do século XIX.
Também é interessante a diagramação do conto. Ele se inicia com "Moço, não, [...]", escrito em vermelho, assim como todos os outros contos da obra, fazendo jus ao tema e ao nome Angu de sangue (FREIRE, 2005). Não apenas o nome e a frase de Socorrinho são pequenos, o conto também tem tamanho reduzido, cabendo em apenas duas páginas. Pequenos também parecem ter sido os esforços da polícia para encontrar a menina. Uma polícia que simboliza autoridade, mas que não é ou não consegue ser competente, visto que se mostra confusa quanto ao caso investigado. "[...] a polícia que alega estupro, magia negra, sequestro, mastiga um fósforo [...]" (FREIRE, 2005, p. 47).

A expressão "mastiga um fósforo" não apenas mostra o comportamento estereotipado do policial, exibido em novelas e filmes antigos, mas sugere o descaso, a falta de preocupação do sistema policial, que não tem sucesso nas buscas como demonstram os fragmentos "[...] batidas de polícia em favelas, rodoviárias, botecos, matagais, tudo isso feito e desfeito [...]; [...] moço, não, descaso, [...]" (FREIRE, 2005, 48). A palavra desfeito pode reforçar a indiferença com que a polícia tratou do sumiço da menina, talvez por pertencer a uma classe desfavorecida e excluída socialmente. É o que diz a voz, provavelmente, de alguém da comunidade onde vivia Socorrinho: “[...] pra que deixar sofrendo a mãe humilde, o bairro [...]" (FREIRE, 2005, 48).

Por outro lado, demonstra-se que a polícia, embora desinformada, procurou a menina, fez batidas nas favelas, rodoviárias etc., permitindo que o leitor relativize seu olhar sobre o trabalho policial, não culpabilizando a polícia sem critérios, pois, se tantas batidas foram feitas, por que não houve sucesso? Esse é um bom exemplo do diálogo inacabado de que trata Bakhtin (2008, p. 4). Não há uma única resposta perceptível no conto, o leitor pode formular várias hipóteses: descaso, precárias condições em que trabalha a polícia em confronto com bandidos espalhados e acobertados pela massa e pelo barulho das grandes cidades. 
Michaud, ao distinguir estados de violência de atos de violência, esclarece que abandono também é uma forma de violência e essa negligência não se refere somente a casos específicos, como se verificou no trabalho da polícia em relação à Socorrinho, mas também ao estado inseguro da atual sociedade.

Pode-se matar, deixar morrer de fome ou favorecer condições de subnutrição. Pode-se fazer desaparecer um adversário ou afastá-lo progressivamente da vida social e política através de uma série de proibições profissionais e administrativas. Aqui aparece claramente a distinção entre estados e atos de violência (MICHAUD, 1989, 11).

A violência, dessa forma, atinge a família de modo permanente na medida em que Socorrinho não é encontrada. O tempo passa velozmente e quanto mais ele corre, mais aumenta a dor da família e há a transformação desse sentimento em outros, como se poderá observar. Esse tempo fugaz é concretizado discursivamente pela voz do narrador em terceira pessoa misturada a outras vozes, como a da mídia sensacionalista. Isso ocorre muitas vezes, por meio da recorrência a advérbios de tempo e marcadores temporais que denotam a passagem do tempo na mesma proporção em que aumenta o sofrimento, o desespero, a raiva, a desesperança e a saudade da filha roubada.

Discurso, tempo, sentimentos, ações estão entrelaçados de tal modo que a narração começa com a fala da menina, quando ela já estava em poder do bandido, e vai se repetindo em meio à narração com predomínios de verbos no tempo presente do modo indicativo, para só no final mostrar o estupro da criança com verbos conjugados no pretérito imperfeito também do modo indicativo. A técnica empregada, nesse caso, é parecida com algumas utilizadas em programas de televisão: o suspense encarrega-se de enredar a atenção do espectador. De modo similar, procede Marcelino Freire ao criar no leitor a expectativa sobre o destino de Socorrinho e somente depois da leitura quase concluída - o que pode ser feito rapidamente - o leitor descobre o que aconteceu.

Podemos ainda destacar no campo linguístico algumas marcações temporais que estão intimamente atreladas aos sentimentos e ações. Na mesma proporção com que o tempo passa, reduz a especulação da imprensa, cessa o trabalho da polícia e aumentam-se e modificam-se os sentimentos da família. Observe: “[...] hoje desaparecida menina de seis anos, ou sete, trajada de camiseta, sapatinhos ou chinelos, descalça, [...]" (FREIRE, 2005, p. 47, grifos nossos). Aqui, marca-se o tempo presente por meio da voz da imprensa e também suas dúvidas quanto às informações. Imprensa que, além de desinformada, apresenta um discurso preconceituoso em relação à menina desaparecida, descrevendo-a como "mulatinha”, além de sugerir que "um negro" seja o responsável pelo crime.

[...] viver agora o que seria se já não era, se por um descuido já se foi um dia sem ela, dois, Socorrinho, céus e preces, moço, não, Maria do Socorro Alves da Costa, mulatinha, sumiu misteriosa, diz uma testemunha que um negro levou sua filha embora [...] (FREIRE, 2005, p. 47-48, grifos nossos).

Observa-se, nesse fragmento, que o tempo transcorre e o sofrimento aumenta. Entretanto, a fragilidade da família é uma constante, ela já existia antes do sumiço de Socorrinho. Basta retomar o trecho "[...] viver agora o que seria se já não era" (FREIRE, 2005, p. 47-48). Situação de vulnerabilidade a que a família se submetia, remetendo novamente às considerações de Michaud (1989) acerca dos estados de violência. Em outro trecho, observa-se:

[...] revolta da família, vizinho, jornal, televisão, igreja, depois de dois meses, moço, não, boneca, foto de batizado, festinha de bairro, tudo que pudesse trazer Socorrinho de volta para a memória, peito, o quarto morto, as horas puxando apreensão, suor, desesperança [...] (FREIRE, 2005, p. 48, grifo nosso). 
De modo telegráfico e econômico, o trecho anterior revela a mobilização da família ao procurar a menina de todas as formas. As horas passam, os sentimentos se modificam, surgem raiva e desesperança, segundo o narrador em terceira pessoa. A família tenta resgatar a memória da menina por meio dos objetos "boneca", "foto de batizado". A expressão "quarto morto" pode ser um indício de que Socorrinho não voltará mais para casa. Contudo, no nível discursivo, ela é trazida ao presente da narrativa o tempo todo, por meio da sua fala pequena, única e repetida "moço, não" (FREIRE, 2005). Tal fala mantém o leitor sem a informação da morte da criança, que será sugerida pelo narrador somente nas últimas linhas. O tempo continua passando, marcado por vozes de diferentes instâncias:

[...] já noitinha de outra noite, mais outra, notícia mais nenhuma, nunca, [...] gritava três meses, cinco, infinitamente, crônica policial, fichário, esquecida realidade, extraí-la do sonho, para sempre, no horizonte, trajada de camiseta, sapatinhos ou chinelo [...] (FREIRE, 2005, p. 48).

A menina sofria a cada dia, o verbo "gritava" confirma isso. Socorrinho não voltou para casa, os advérbios "nunca", "infinitamente" e a locução adverbial "para sempre" reafirmam a impossibilidade de encontrar a criança, que só poderia ser resgatada pela memória, pelo "sonho". A imprensa silencia e o sumiço da garota pobre é "esquecida realidade". Este silêncio somado à forma como se noticiou o fato - preconceito para com o afrodescendente - também são formas de violência. Michaud trata dessa questão quando adverte que: "A violência são os fatos tanto quanto nossas maneiras de apreendê-los, de julgá-los, de vê-los ou de não vê-los" (1989, p. 11). Socorrinho não apenas desapareceu como foi violentada. No momento próximo ao estupro, ela amplia seu vocabulário minguado, pequeno, assim como aumenta seu medo:
Moço, não, descaso, não escuto, moço, não, quero ir pra casa, não, moço, não, o homem arreava as calças, mais o grito, moço, não, não, Socorrinho chorava, Socorrinho esperneava, Socorrinho mais não entendia aquele mundo estranho, aquele desmaio de anjo. (FREIRE, 2005, p. 49, grifo nosso)

Socorrinho acrescenta uma sequência de quatro palavras especiais e de muito significado para todo ser humano: "quero ir pra casa". A casa é o porto seguro de todos, porém não mais para a garotinha, que não voltaria e teria a sua inocência violada. Pode-se dizer que Socorrinho perdeu sua casa, sua inocência, sua vida, pois a sequência poética "desmaio de anjo" sugere violência contra um inocente como também pode significar a sua morte, pela associação da palavra "anjo", do campo semântico espiritual, à palavra "desmaio", no sentido de (des)falecimento.

Como se percebe, falar de violência não elimina a possibilidade de se escrever textos esteticamente bem elaborados e até com muita poesia. Marcelino Freire consegue, em meio a uma história tão triste, ser muito poético. É o que se pode depreender de alguns fragmentos como os que se seguem: "[...] Socorrinho, algumas buzinas, céu de gasolina, ozônio, [...]" (FREIRE, 2005, 56). Aqui, o chamado da mãe se mistura à paisagem da cidade, mas há poesia no uso da rima "buzinas"/"gasolina"; há ainda a aliteração conferindo sonoridade, para citar apenas um exemplo. A poesia se faz presente também por meio de outro recurso utilizado pelo autor, o da intertextualidade, reforçando a opção de Freire em chamar outras vozes para a sua narrativa.

Trata-se da voz de outro conto, de outra época: “[...] trajada de camiseta sapatinhos ou chinelo, descalça, fita crespa no cabelo, azul forte ou infinito [...]" (FREIRE, 2005, p. 48, grifo nosso) ${ }^{1}$. A morte aparece nos dois textos, no

${ }^{1}$ o trecho destacado "fita crespa no cabelo" dialoga com o conto "Fita verde no cabelo: nova velha história" (2016), de João Guimarães Rosa, publicado, originalmente, em 1964, no jornal O Estado de São Paulo. Esse conto, por sua vez, faz uma releitura do conto de fadas Chapeuzinho Vermelho. No 
de Guimarães é a avó quem morre, no de Freire, é Socorrinho. A menina da fita verde decide o caminho a seguir; Socorrinho é roubada e não entende o que acontece com ela. Fita verde ainda tem medo; Socorrinho tem horror, basta lembrar-se das imagens "dor de dente", "comprimido", usadas para descrever as sensações da menina raptada. No conto de Guimarães Rosa, a morte é um processo natural, a avó morre por estar velha, Socorrinho morre ainda criança, antes da hora, por causa da fúria de alguns indivíduos. Fita verde quis ir ao encontro da avó; Socorrinho foi levada à força para a morte.

Como se disse, no conto de Rosa, não há mais lobos, foram exterminados pelos lenhadores, no de Freire, eles ainda existem na figura dos assassinos, que se produzem em parte pela sociedade desigual do Brasil e também pela ineficiência da polícia, que se metaforiza na figura do lenhador, porém incompetente. Fita verde estava suada de brincar pelo caminho, conforme diz o texto: "Mas agora Fita Verde se espantava, além de entristecer-se de ver que perdera em caminho sua grande fita verde no cabelo atada; e estava suada, com enorme fome de almoço" (ROSA, 2016, grifo nosso). Socorrinho também suava, mas de medo: "Moço não, sua mão, suando, grito no semáforo, em contramão, suada, pelos carros, [...]" (FREIRE, 2005, p. 47, grifo nosso). Conclui-se, assim, que a voz de Guimarães Rosa foi utilizada para, no jogo comparativo entre as meninas, reforçar a violência sofrida por Socorrinho, honrando a construção primorosa do escritor mineiro. Fica patente que Freire, ao escrever "fita crespa no cabelo, azul forte ou infinito" (FREIRE,

conto de Guimarães Rosa, diferente do clássico, não existe mais o lobo porque ele foi exterminado pelos lenhadores, e no lugar de uma menina obediente, há uma garota com uma fita verde no cabelo, desobediente, que escolhe seguir por um caminho longo, contrariando a instrução da mãe. Ela "Saiu, atrás de suas asas ligeiras" e divertiu-se nesse caminho com as flores, borboletas etc. Quando chega à casa da avó, percebe que perdera sua fita verde no caminho e se depara com a voz doente da avó, que acaba morrendo devido à idade. Nesse momento, a menina diz que tem medo de lobo. Se não há mais lobo fica lobo, fica claro que lobo significa a morte e que a menina, ao escolher o caminho que quis, estava em processo de amadurecimento, vez que estava "atrás de suas asas ligeiras" e que perde a fita, símbolo da morte no universo de uma garota em busca de identidade e descoberta.
2005,48 , grifo nosso), quis resgatar a vida de Socorrinho que poderia ter sido, mas que não foi.

\section{Em síntese}

Verifica-se que Marcelino Freire, no conto "Socorrinho", expressa uma visão provocativa sobre um tema recorrente na literatura e na realidade contemporânea, o da violência. 0 autor consegue ser atual, fazendo uso dos recursos do novo realismo sem negar seus predecessores no trato com a arte literária. Torna-se, assim, um escritor preocupado com os temas da sociedade de hoje, mas não abdica do cuidado com a forma.

Freire, com poucas palavras e de um só fôlego, apreende a realidade e a extrapola, cumprindo com as palavras de Cortazar (2011) sobre o gênero conto, iluminando uma "história miserável" como a da personagem Socorrinho, preservando a condição de sujeito dos personagens. Da mesma forma, protagoniza os ensinamentos de Érico Veríssimo, acendendo bruscamente a luz elétrica sobre a realidade escura de muitas pessoas em alguns espaços citadinos, não deixando, portanto, passar despercebidas as atrocidades presente na vida contemporânea. 0 leitor, por mais insensível ou inexperiente que seja, há de se iluminar e inquietar-se com a proximidade e estranheza do conto Socorrinho, para repensar alguns aspectos banalizados ou destratados pela mídia, como a violência, para se reorganizar interiormente e para se humanizar.

\section{Referências}

BAKHTIN, Mikhail. Marxismo e filosofia da linguagem. Trad. Michel Lahud et al. São Paulo: Hucitec, 2006.

Problemas da poética de Dostoiévski. Trad. Paulo Bezerra. Rio de Janeiro: Forense Universitária, 2008. 
BRANDILEONE, Ana Paula Franco Nobile. Literatura brasileira contemporânea: caminhos diversos. In: BRANDILEONE, Ana Paula Franco Nobile; OLIVEIRA, Vanderléia da Silva (Org.). Desafios contemporâneos: a escrita do agora. São Paulo: Annablume, 2013.

OLIVEIRA, Vanderléia da Silva. A narrativa brasileira no século XXI: Ferréz e a escrita do testemunho, Navegações, Porto Alegre, v. 7, n. 1, p. 23-30, jan.-jun. 2014. Disponível em: <http://revistaseletronicas.pucrs.br/ojs/index.php/navegacoes/article/ view/14250>. Acesso em: 30 maio 2016.

CANDIDO, Antonio. A literatura e a vida social. In: Literatura e sociedade. São Paulo: Publifolha, 2000.

. A nova narrativa. In: A educação pela noite e outros ensaios. São Paulo: Ática, 1989.

$\mathrm{O}$ direito à literatura. In: . Vários escritos. São Paulo: Duas Cidades, 1995.

CORTÁZAR, Julio. Alguns aspectos do conto. In: Valise de cronópio. São Paulo: Perspectiva, 2011.

DUARTE, Lia Cupertino. Lobato humorista: a construção do humor nas obras infantis de Monteiro Lobato. São Paulo: Unesp, 2006.

FERNANDES, Giséle Manganelli. O Pós-Modernismo. In: BONNICI, Thomas; ZOLIN, Lúcia Osana(Orgs). Teoria literária: abordagens históricas e tendências contemporâneas. Maringá: EDUEM, 2009.

FERNANDES, Rinaldo de. O conto brasileiro do século 21. Rascunho, Curitiba, n. 121, p.11-15, maio 2010. Disponível em: <http://rascunho.com.br/wp-content/uploads/ 2011/12/Book_121.pdf>. Acesso em: 24 Maio 2016.

FRANCO, Adenize. Sangue derramado. Rascunho. Curitiba, n. 140, dez. 2011. Disponível em: <http://rascunho.com.br/sangue-derramado/>. Acesso em: 30 maio 2016.

FRANCO JUNIOR, Arnaldo. Operadores de leitura da narrativa. In: BONNICI, Thomas; ZOLIN, Lúcia Osana (Org.). Teoria literária: abordagens históricas e tendências contemporâneas. Maringá: EDUEM, 2009.

FREIRE, Marcelino. Socorrinho. In: Angu de Sangue. São Paulo: Ateliê Editorial, 2005.

FREIRE, Marcelino. Ossos do Ofídio. 2016. Disponível em: <https://marcelinofreire. wordpress.com/marcelino-freire/>. Acesso em: 15 abr. 2016.

GOTLIB, Nádia Battella. Teoria do conto. São Paulo: Ática, 2006.

JOUVE, Vincent. A leitura. São Paulo: Unesp, 2002.
Por que estudar literatura? São Paulo: Parábola, 2012.

LYRA, Pedro. Apresentação. In Brasileiro, 1980.

MICHAUD, Yves. A violência. São Paulo: Ática, 1989.

OLIVEIRA, Vanderléia da Silva. A representação da violência na narrativa brasileira contemporânea. In: BRANDILEONE, Ana Paula Franco Nobile; OLIVEIRA, Vanderléia da Silva (Org.). Desafios contemporâneos: a escrita do agora. São Paulo: Annablume, 2013.

PEREIRA, Helena Bonito; LOPONDO, Lílian. Introdução. In: PEREIRA, Helena Bonito (Org.). Novas leituras da ficção brasileira no século XXI. São Paulo: Universidade Presbiteriana Mackenzie, 2011.

PEREIRA, Márcia Moreira. Marcelino freire: um escritor da metrópole caótica. Revista Literatura. Ed. 53, 2014. Disponível em: http://literatura.uol.com.br/literatura/figuraslinguagem/53/sumario.asp. Acesso em: 12 mar. 2016.

RESENDE, Beatriz. Contemporâneos: Expressões da Literatura Brasileira no século XXI. Rio de Janeiro: Casa da Palavra/Fundação Biblioteca Nacional, 2008.

ROSA, Guimarães. Fita verde no cabelo. Disponível em: <https://mariacarolinatorres. wordpress.com/2011/02/18/fita-verde-no-cabelo-joao-guimaraes-rosa/>. Acesso em: 28 maio 2016.

SCHØLLHAMMER, Karl Erik. Ficção brasileira contemporânea. Rio de Janeiro: Civilização Brasileira, 2009.

SCHØLLHAMMER, Karl Erik. Os cenários da violência na literatura brasileira. In: PEREIRA, Carlos Alberto Messeder et al. (Org.). Linguagens da violência. Rio de Janeiro: Rocco, 2000. p. 237-59.

VERÍSSIMO, Érico. Solo de clarineta. São Paulo: Companhia das Letras, 1978.

Recebido em 19/07/2016.

Aceito em 17/12/2016. 